\title{
Introduction: Updating Mill on Free Speech
}

\author{
Piers Norris Turner \\ Ohio State University, Ohio State University, Columbus, OH, USA \\ turner.894@osu.edu
}

\begin{abstract}
John Stuart Mill's defense of freedom of discussion in On Liberty remains a major influence on philosophical and public debates about free speech. By highlighting underappreciated textual evidence and key distinctions, this introduction attempts to show how the contributions of the symposium authors - Melina Constantine Bell, Rafael Cejudo, Christopher Macleod, and Dale E. Miller - point toward a more complete account of Mill's views.
\end{abstract}

\section{Introduction}

John Stuart Mill's defense of freedom of discussion in On Liberty (1859) remains a major influence on philosophical and public debates about free speech. A regular stream of articles, commentaries, and letters to the editor imagine Mill's verdict on related topics, such as tolerating the public expression of extreme or hateful viewpoints, promoting underrepresented voices on university campuses, broadening the perspectives found in the mainstream media, giving space in textbooks to science skeptics, and the role of civility in public discourse.

Generally speaking, Mill is invoked on one side of these debates: as an advocate for unrestricted freedom of discussion due to the epistemic (and, ultimately, social) benefits of viewpoint diversity, the related need to provide a public check on authority, and the personal value of individuality. This is the core of Mill's liberal argument for free discussion. And so we are told to tolerate others' expression of opinion, even if the opinion is disrespectful or false, because critical challenge is an important means to intellectual and social development, while restricting the expression of opinion on public matters is a dangerous form of social control. ${ }^{1}$

Are there limits to Mill's argument? Some commentators note his openness to restricting expression of opinion that constitutes "instigation to some mischievous act."

\footnotetext{
${ }^{1}$ Mill's argument in chapter 2 of On Liberty is among the most important in the history of liberal political philosophy, but I worry about one-sided presentations of it. The most striking recent example is the Heterodox Academy's melodramatic rendering of it in graphic novel form: <https://heterodoxacademy.org/ library/all-minus-one/> [accessed 9 January 2020]. I think Mill was sensitive to many of the issues that make some free speech cases so difficult.

${ }^{2}$ John Stuart Mill, On Liberty, in Collected Works of John Stuart Mill, ed. by J. M. Robson and others, 33 vols (Toronto: University of Toronto Press; London: Routledge and Kegan Paul, 1963-91), XVIII, p. 260. Herewith, citations of Mill marked by "CW volume number, page number" refer to the Collected Works. 
His famous example in On Liberty itself is of someone declaring "corn dealers are starvers of the poor" to an angry mob outside a corn dealer's home. It is rarely observed, however, that in a number of other writings he also supports restrictions on expressions of opinion when they amount to private libel, instigation to treason, threats to "the safety of the public peace," or violations of "public decency." 3 This forces us to consider the question: if his liberal argument in chapter 2 of On Liberty is not meant to protect all speech, or even all expression of opinion, what exactly counts as "discussion" such that it should never be restricted? Conversely, why do only some harms associated with the expression of opinion justify restrictions, and where do we draw the line?

In addition to this, the contingent nature of Mill's argument - appealing to the educative and democratic aims of public discussion mentioned above - suggests that he could support regulation of discussion where those aims would otherwise be threatened. The contingency of the argument is highlighted by his comments that discussion may be restricted in "moments of panic" and that a "temporary dictatorship" could be justified in times of "extreme exigency" as long as it is committed to the restoration of a free and democratic society. ${ }^{4}$ In non-crisis circumstances, it seems likely that Mill would conclude that any restriction on discussion ultimately makes things worse. But the point is: he would not simply disregard new evidence affecting the realization of his aims - for example, evidence that free discussion sometimes discounts or diminishes the voices of the less powerful.

If freedom of discussion turned out to hinder our learning from each other, under certain circumstances, that would be an important finding for Mill. Already in On Liberty, he notes the unfair ability of dominant groups to "stigmatize those who hold the contrary opinion as bad and immoral." Even as he defends freedom of discussion against formal restriction, he also ends his chapter by characterizing a "real morality of public discussion," to be enforced by the opinion of interlocutors themselves:

condemning every one, on whichever side of the argument he places himself, in whose mode of advocacy either want of candour, or malignity, bigotry, or intolerance of feeling manifest themselves; but not inferring these vices from the side which a person takes, though it be the contrary side of the question to our own: and giving merited honour to every one, whatever opinion he may hold, who has calmness to see and honesty to state what his opponents and their opinions really are, exaggerating nothing to their discredit, keeping nothing back which tells or can be supposed to tell, in their favour. ${ }^{6}$

Mill's defense of freedom of speech in chapter 2 begins to look rather like a defense of not restricting viewpoints in frank and fair-minded public discussion. That is a more limited, though still very important, claim. And it leaves open key questions, such as whether Mill intends to protect manipulative, demeaning, or coercive expression of opinion tied to significant harms. ${ }^{7}$ What, then, is his settled overall view of what speech should or should not be protected?

\footnotetext{
${ }^{3}$ See section 4 for citations and discussion of these cases.

${ }^{4}$ Mill, On Liberty, CW XVIII, p. 228n.; Mill, Considerations on Representative Government, CW XIX, p. 403.

${ }^{5}$ Mill, On Liberty, CW XVIII, p. 259.

${ }^{6}$ Ibid., p. 259.

${ }^{7}$ To be clear, Mill defends the use of "intemperate" language within discussion as sometimes important for non-dominant views to get a hearing (CW XVIII, pp. 258-59). The question is: what goes beyond discussion?
} 
This symposium aims to refocus attention on Mill's arguments, to better appreciate their significance for today's debates. I am grateful to the authors - Melina Constantine Bell, Rafael Cejudo, Christopher Macleod, and Dale E. Miller - for their illuminating contributions. ${ }^{8}$ What follows is a brief guide to the questions under consideration, revealing (I hope) how the essays in this symposium point toward a more complete account of Mill's views on freedom of speech.

\section{The main elements of chapter 2 of On Liberty}

Mill's conclusion in chapter 2 of On Liberty is that there should be absolute freedom of discussion in stable, cooperative societies. ${ }^{9}$ The main argument is that whether received opinion is possibly false or certainly true, the harm of restricting free discussion always outweighs its benefits. If received opinion is possibly false, Mill says, restrictions cost us the opportunity to exchange falsehood for truth, or worse partial truth for better partial truth. If received opinion is certainly true, we still lose something important: the opportunity to recall the rational grounds of, and to keep vital, true belief.

Two further claims deserve special mention. First, Mill argues that any indefinite restriction of discussion involves social or political authority in an "assumption of infallibility." In other words, on the topic being restricted, censors take up a position of epistemic superiority with respect to future decision-makers that they are not entitled to take up (i.e. one which only infallibility could justify). ${ }^{10}$ By contrast, in protecting free discussion, decision-makers "take precautions against their own fallibility." 11 Second, Mill argues that freedom of discussion is required for social or political authority's decisions to remain based on reasons and not on their mere "likings or dislikings." 12

These arguments show that discussion is vitally important as the mechanism that ties decisions to the lessons of experience and reasoned justification, facilitating individual development and social progress. "[T]he source of everything respectable in man either as an intellectual or moral being," Mill writes, is that he "is capable of rectifying

\footnotetext{
${ }^{8}$ This symposium grew out of a panel at the 2019 meeting of the Philosophy, Politics, and Economics Society in New Orleans, where drafts of three of these articles (Bell, Macleod, Miller) were first presented. The invited pieces by Bell and Macleod were included after extensive feedback from me, as symposium editor, and Miller, as editor of Utilitas and an area expert. Because Miller is editor of this journal, his submission underwent blind review (with three referees). In light of that feedback, I made the decision to include it in the symposium. Cejudo's contribution was submitted independently, and likewise underwent blind review.

${ }^{9}$ But (as mentioned already), Mill's case is not really absolute, given his allowances for "moments of panic" or cases of "extreme exigency."

${ }^{10}$ In this, I have tried to show, Mill follows Bentham. See Piers Norris Turner, Authority, Progress, and the "Assumption of Infallibility" in On Liberty, Journal of the History of Philosophy, 51 (2013), 93-117.

${ }^{11}$ Mill, On Liberty, CW XVIII, p. 229. In an underappreciated passage from Mill's essay on Bentham, he emphasizes that people's circumstances limit their perspectives: "[E]very inquirer is either young or old, rich or poor, sickly or healthy, married or unmarried, meditative or active, a poet or a logician, an ancient or a modern, a man or a woman; and if a thinking person, has, in addition, the accidental peculiarities of his individual modes of thought. Every circumstance which gives a character to the life of a human being, carries with it its peculiar biases; its peculiar facilities for perceiving some things, and for missing or forgetting others. But, from points of view different from his, different things are perceptible; and none are more likely to have seen what he does not see, than those who do not see what he sees" (Mill, Bentham (1838), CW X, pp. 90-91).

${ }^{12}$ Mill, On Liberty, CW XVIII, p. 222.
} 
his mistakes, by discussion and experience."13 Discussion is also needed to hold decision-makers accountable to public opinion. Like Jeremy Bentham and James Mill, John Stuart Mill was concerned to maintain an "identity of interest" between the rulers and the ruled, and for all of them free discussion is vital to any effective democratic check on social and political authorities. ${ }^{14}$ To silence discussion, then, is to undermine these key liberal and democratic goods.

\section{Does Mill's argument rely on the liberty principle?}

Notably absent from my summary of chapter 2 is any mention of Mill's famous "harm" or "liberty" principle, according to which society may consider interference with individual liberty only when there is risk of nonconsensual harm to others. Doesn't Mill claim that the expression of opinion or discussion is, strictly speaking, harmless? Some recent commentators, including Macleod, John Skorupski, Jonathan Riley, and myself, have argued that Mill simply doesn't make his case that way. ${ }^{15}$ That is, he does not say that expression of opinion or discussion never risks nonconsensual harm to others (and is therefore outside of society's jurisdiction), but only that society should not interfere with discussion because its benefits always outweigh its costs. ${ }^{16}$ If that is correct, then chapter 2 is independent of liberty principle reasoning - though it is still part of Mill's broader articulation of the value of liberty.

Miller's contribution to this symposium, "The Place of 'The Liberty of Thought and Discussion' in On Liberty," provides valuable pushback against this general approach. Appealing to textual cues, especially from chapter 1, he defends a "continuity interpretation" on which Mill's defense of freedom of discussion in chapter 2 follows naturally from the introduction of the liberty principle in chapter 1 . The continuity interpretation turns (to a large extent) on the claim that "as a general rule - in the great majority of cases, if not literally all - discussion is self-regarding," that is, it does not risk nonconsensual harm to others. ${ }^{17}$ If expression of opinion is self-regarding or harmless, then it falls outside of society's jurisdiction. This is not to deny that there are some "cases in which expression is directly harmful," but Miller argues that, on Mill's view, these are "infrequent departures from the norm." 18

The nature of Mill's reasoning is important because it affects our sense of the limits of his argument and of his openness to revising his conclusions. One source of skepticism about Mill's relevance today just is the thought that expression of opinion often risks harm that his theory doesn't take into account - something Miller addresses in the final section of his article. As we shall see, Bell makes this issue the centerpiece

\footnotetext{
${ }^{13}$ Mill, On Liberty, CW XVIII, p. 231.

${ }^{14}$ Mill, Appendix B to Dissertations and Discussions, vol 1 (1859), CW XIX, p. 648.

${ }^{15}$ John Skorupski, John Stuart Mill (London: Routledge, 1989), p. 369, Jonathan Riley, J. S. Mill's Doctrine of Freedom of Expression, Utilitas, 17 (2005), 147-79; Christopher Macleod, Mill on the Liberty of Thought and Discussion, in The Oxford Handbook on Freedom of Speech, ed. by Adrienne Stone and Frederick Schauer (Oxford: Oxford University Press, 2021), pp. 3-19; Piers Norris Turner, The Arguments of On Liberty: Mill's Institutional Designs, Nineteenth-Century Prose, 47 (2020), 121-56.

${ }^{16}$ Here I am setting aside the "assumption of infallibility" (A/I) argument, which seemingly limits altogether society's authority to silence discussion, though not by use of liberty principle reasoning. The limits imposed by the A/I argument, and the limits of those limits, is an interesting issue. See Turner, Authority, Progress, and the "Assumption of Infallibility" in On Liberty.

${ }^{17}$ Dale E. Miller, The Place of "The Liberty of Thought and Discussion" in On Liberty.

${ }^{18}$ Ibid.
} 
of her Millian reclamation project in "John Stuart Mill's Harm Principle and Free Speech: Expanding the Notion of Harm.”

\section{What kinds of expression amount to harms that might be restricted?}

One curiosity of the literature on Mill's defense of free discussion is the general failure to focus on the many cases in which he believes expression of opinion on balance should be restricted, and the need to draw some lines between those cases and whatever is covered by chapter 2 . Let me summarize some of the evidence, which extends beyond On Liberty.

In "Mr. O'Connell's Bill for the Liberty of the Press" (1834), a robust early defense of free discussion, Mill is clearer about limits. He writes first that "Discussion on the subject of religion ought to be perfectly free." But with respect to politics, he refines the point: "[I]t shall be lawful to controvert any political doctrine, or attack any law or institution, without exception; in any manner and in any terms not constituting a direct instigation to an act of treason, or to some other specific act to which penalties are attached by the law." 19 He does not specify which illegal acts he has in mind, but one could imagine instigation to violence or threats to public safety as the next obvious candidates.

These are not the only issues, however. In that same article, Mill argues that private libel, concerning conduct that does not bear upon "the public character" of a person, ought to be restricted even when the allegation is true. It is an invasion of privacy; only when conduct becomes public in one way or another should it be open to public disapprobation or censure.

In On Liberty itself, as we saw before, Mill introduces the corn dealer case as an example of incitement or "instigation to some mischievous act." ${ }^{20}$ He there also asserts that instigation to tyrannicide (despite its often being considered a virtuous act in the end) "may be a proper subject of punishment." ${ }^{21}$ Just as Mill did not specify the acts "to which penalties are attached by the law" he had in mind, he does not specify all "mischievous" acts either. But it bears mentioning that both turns of phrase suggest that more acts than just threats or incitement to violence may be included.

Finally, in "Thornton on Labour and its Claims" (1869), Mill considers the case of union members expressing their frustration at workers who benefit from the union's efforts but are unwilling to make sacrifices themselves. In line with the earlier discussions, he first says that while it is justifiable for those workers "to have brought before them, in an impressive manner, what their fellow-workmen think of their conduct" there should be no "threat of infringement of any of the rights which law guarantees to all - security of person and property against violation, and of reputation against calumny." 22 He then addresses "picketing" as a difficult case, and writes:

Hooting, and offensive language, are points on which a question may be raised; but these should be dealt with according to the general law of the country. No good reason can be given for subjecting them to special restriction on account of the occasion which gives rise to them, or to any legal restraint at all beyond

\footnotetext{
${ }^{19}$ Mill, Mr. O'Connell's Bill for the Liberty of the Press, CW VI, p. 166; emphasis added.

${ }^{20}$ Mill, On Liberty, CW XVIII, p. 260.

${ }^{21}$ Ibid., p. $228 \mathrm{n}$.

${ }^{22}$ Mill, Thornton on Labour and Its Claims, CW V, p. 660; emphasis added.
} 
which public decency, or the safety of the public peace, may prescribe as a matter of police regulation. ${ }^{23}$

Here, Mill explicitly cites the safety of the public peace and public decency as reasons capable of justifying restrictions on expression of opinion.

How should we make sense of these cases of incitement, threat, private libel, public safety, and public decency? One might argue that they are just a handful of specific exceptions to the protection of expression of opinion. But if we want to understand how to update Mill on free speech, our challenge is to see how he can both allow restrictions on a range of expression of opinion and argue for absolute freedom of discussion.

The first part of this challenge is, I think, answered by an underappreciated comment Mill makes about Montesquieu in his earliest writing on the topic, "Law of Libel and Liberty of the Press" (1825). He writes that Montesquieu saw correctly that "the only case in which the expression of opinions and sentiments could be a fit object of punishment" is when - and here he begins quoting Montesquieu - "the words that are joined to an act take on the nature of that action." Montesquieu gives this example: "a man who goes into the public square to exhort the subjects to revolt becomes guilty of high treason, because the speech is joined to the act and participates in it [. . . Speech becomes criminal only when it prepares, when it accompanies, or when it follows a criminal act." ${ }^{24}$ Mill emphasizes that Montesquieu's argument could extend to cases beyond treason, and we have already seen ways in which he does extend it. But then, we are presented with the following question: are there other expressions of opinion that, in certain circumstances, become joined to criminal or harmful acts such that we may restrict the expression itself? If so, Mill should be open to those restrictions, at least in principle.

Bell's article picks up at exactly this point, arguing that "bigoted insults" are fit objects of restriction because of the harms they are tied to: "[B]ecause bigoted speech causes direct harm to individuals, and plays a central role in maintaining and perpetuating institutional oppression and injustice, it causes not merely subjective unpleasant mental states or offense, but also serious harms that usually remain unrecognized both in law and in public discussion." 25 This expanded sense of harmful expression, Bell argues, reflects new psychological and social scientific evidence that Mill did not have at his disposal. She concludes that, on his own terms, Mill should agree that bigoted speech is open to restriction because it is harmful, while offering none of the educative or democratic benefits he associates with discussion.

The second part of the challenge - how can Mill then defend absolute freedom of discussion? - might simply be answered by understanding "discussion" as any expression of opinion that is not joined to a harmful act in the way described. Is that right?

\section{What is "discussion"?}

So far we have seen that Mill's argument in chapter 2 concerns only expressions of opinion that are not joined to some harmful act justifying a restriction. But Mill

\footnotetext{
${ }^{23}$ Ibid., p. 660.

${ }^{24}$ Mill, Law of Libel and Liberty of the Press, CW XXI, p. 5. Mill quotes Montesquieu in French. I am providing the translation from Montesquieu, The Spirit of the Laws, ed. by Anne M. Cohler, Basisa C. Miller, and Harold S. Stone (Cambridge: Cambridge University Press, 1989), pp. 198-99.

${ }^{25}$ Melina Constantine Bell, John Stuart Mill's Harm Principle and Free Speech: Expanding the Notion of Harm.
} 
must be saying something more, or at least more specific; it would be trivial to assert that where the benefits of restricting expressions of opinion do not outweigh the costs of restriction, the benefits of restriction do not outweigh the costs of restriction.

One way of approaching this question would be to return to the topic of Miller's article. Perhaps Mill's distinctive contribution is to argue that in a wide range of cases falling short of instigation, private libel, threats to public safety, public indecency, and so forth, expression of opinion is properly understood as "self-regarding," and therefore interference is not even open to consideration. We would then want to understand what that range of expression is - something Miller addresses - when so much expression of opinion does seem to risk harm to others, on Mill's view.

Another way to approach this question would be to notice how consistently Mill uses the term "discussion" in defining the topic of chapter 2, and then to ask what distinguishes discussion from other expressions of opinion. Macleod's article, "Truth, Discussion, and Free Speech in On Liberty II," pursues a novel version of this second approach. He leans on the distinctively epistemic nature of the arguments of chapter 2 to argue that, for Mill, "discussion" is an epistemic practice aiming at truth that consists only in "the statement and consideration of truth-apt propositions." 26 On Macleod's account, then, Mill's absolute support for free discussion in chapter 2 is only as an epistemic matter, and not an all things considered claim, despite appearances. That is, in cases of incitement, private libel, and so forth - when restrictions are justified - what happens is that non-epistemic reasons come to outweigh the epistemic reasons.

The key thought for the second approach, in general, is that Mill's argument in chapter 2 focuses on "discussion" understood in some limited way. What Mill would say about other forms of speech or expression of opinion goes beyond the aims of chapter 2 (consider that the corn dealer example is not introduced until chapter 3 ). This is not to say that he would welcome restrictions on other expressions of opinion in the absence of the sorts of reasons mentioned earlier. But on the basis of chapter 2 alone, we should not simply presume that manipulative or demeaning speech, such as Bell's "bigoted insults," would be protected. ${ }^{27}$

One challenge raised by Macleod for his own particular account is that some discussion might not seem to be truth-apt, like flag-burning. Cejudo's article, "J. S. Mill on Artistic Freedom and Censorship," very nicely addresses this issue in the context of works of art. Cejudo argues that, on Mill's own (sketchy) aesthetic theory, art has epistemic relevance despite being "non-assertoric," because it can reveal to us truths about

\footnotetext{
${ }^{26}$ Christopher Macleod, Truth, Discussion, and Free Speech in On Liberty II. His article breaks new ground by placing this practice within Mill's broader "Art of Life." For important background, see his Mill on the Primacy of Practical Reason, Analysis, 78 (2018), 630-38.

${ }^{27}$ My own preferred version of this approach to Mill on "discussion" also emphasizes the importance of epistemic considerations in his calculation of costs and benefits. It holds that discussion is a subset of expression of opinion governed by basic norms of fairness, regard for truth, and sincerity, and that it is this practice that Mill means to defend absolutely and all things considered (Turner, Authority, Progress, and the "Assumption of Infallibility" in On Liberty, pp. 105-07). Does Mill offer an argument in favor of free speech in general, beyond just discussion? In his early essay, "Law of Libel and Liberty of the Press," he writes: "there is no medium between perfect freedom of expressing opinion, and absolute despotism" (CW, XXI, p. 6). This is important evidence of a general concern about the abuse of the power to censor speech, but it is interesting that he does not repeat this argument explicitly in chapter 2 of $\mathrm{On}$ Liberty. I would add that, even in the context of discussion itself, one might wonder what Mill would now think of attempts in some countries to introduce carefully circumscribed limits on the content of discussion (e.g., on denial of the Holocaust) without undermining discussion generally.
} 
human existence. If this is right, then much artistic expression and other epistemically relevant forms of expression deserve the same protections as discussion. Cejudo allows that works of art may sometimes constitute incitement to harm or violate public decency. But he argues that the former cases are very rare, and the latter cases could usually be addressed by hosting the artworks where their audience would have to choose to engage them.

\section{Conclusion}

Mill writes: "there ought to exist the fullest liberty of professing and discussing, as a matter of ethical conviction, any doctrine, however immoral it may be considered." 28 We have been asking why he believes this, and what is packed into the notion of "discussion, as a matter of ethical conviction" that justifies its being unrestricted. In doing so, we have also uncovered some clues about when Mill is willing to consider restrictions on speech. Perhaps the main lesson of this symposium is that we must look beyond just On Liberty for Mill's complete view of freedom of speech.

In the meantime, we do well to heed Mill's admonition:

[t]hat mankind are not infallible; that their truths, for the most part, are only halftruths; that unity of opinion, unless resulting from the fullest and freest comparison of opposite opinions, is not desirable, and diversity not an evil, but a good, until mankind are much more capable than at present of recognizing all sides of the truth. ${ }^{29}$

What the "fullest and freest comparison of opposite opinions" requires in our social and political circumstances is something Mill himself would have us continue to reflect on. $^{30}$

\footnotetext{
${ }^{28}$ Mill, On Liberty, CW XVIII.228 n. 1.

${ }^{29}$ Ibid., p. 260.

${ }^{30}$ For discussion on these topics, I am grateful to Melina Bell, Sigal Ben-Porath, Eric MacGilvray, Chris Macleod, Helen McCabe, and Dale Miller.
}

Cite this article: Turner PN (2021). Introduction: Updating Mill on Free Speech. Utilitas 33, 125-132. https://doi.org/10.1017/S0953820821000029 